\title{
Managing System Of Diesel Fuel Provision By Mapping Fisherman Activities
}

\author{
Reynoldus Andrias Sahulata ${ }^{* 1}$, Po Abas Sunarya ${ }^{2}$ \\ ${ }^{1}$ Fakultas Ilmu Komputer Program Studi Sistem Informasi Universitas Klabat, \\ ${ }^{2}$ Fakultas Sains \& Technology University of Raharja \\ E-mail: ${ }^{* 1}$ rey_sahulata@ unklab.ac.id, ${ }^{2}$ abas@ @raharja.info
}

\begin{abstract}
The certainty of getting diesel fuel oil for the purposes for fishing of fishermen needs to get serious attention from the government, this is due to the many irregularities seen in the fishermen's field before going to sea, to get diesel must deal with the availability of diesel with an affordable price level especially for fishermen who use fishing vessels with volumes of up to $30 G T$ (Gross Ton) must deal with individuals who regulation seaworthy letters that ignore Article 86 of the Minister of Marine Affairs and Fisheries Regulation No. 30 of 2012 concerning Capture Fisheries Business in the Republic of Indonesia's Fisheries Management Area Indonesia is in the form of a Fishing License (SIPI) and a Fishing Vessel License (SIKPI), an Original Operation Feasibility Certificate (SLO) and an Original Sailing Certificate (SPB), which makes it difficult to obtain subsidized diesel fuel that fishermen should have with vessel qualifications up to 30GT. For this reason, the researchers built of arrangement for computerized fishermen's diesel fuelsupply so that the certainty of the availability of diesel fuel in accordance with its designation can be ensured, because all supply and distribution of diesel fuel is regulated to be carried out computerized.
\end{abstract}

Keywords — Arrangement, Database, Fishing Vessel

\section{INTRODUCTION}

Indonesia's territorial waters have the second-longest coastline in the world along 99,000 kilometers, with a water area of 6.3 million square kilometers [1], with an area and abundant wealth of fishery and marine resources that have not all the potentials optimized by fishermen in Indonesia. This is caused by various problems that continue to surround the lives of fishermen in this country. The problem is on the asset side, namely fishermen are still difficult to get boat assistance, then not all fishermen get life insurance provided by the Ministry of Marine Affairs and Fisheries (KKP), until the high cost of diesel to go to sea. This is the result of a study issued between the Ministry of Communication and Informatics and KKP [2].. The Indonesian Institute of Sciences (LIPI) oceanographic research center stated that the value of Indonesia's marine wealth reached $\mathrm{Rp} 1,772$ trillion, with a potential wealth of more than Rp1,700 trillion[3]. This condition is a great opportunity in improving the standard of living of fishermen as well as challenges in supervision, where there is data showing that traditional fishermen face various obstacles such as dealing with fishermen who use trawling trawls, marketing of fish that have not been optimized, as well as protection of fishermen against legal certainty at sea, as happened in the waters of North Sumatra, although trawling has been banned, but still operates. Refusals are often made by traditional fishermen, who do so by reporting to the water police safety apparat but have no significant impact on 
law enforcement resulting in disrupted fishing for traditional fishermen. Also, this has an impact on the destruction of marine biota, with the use of trawling in fishing[4]. In addition to the constraints in fishing with a large distribution of sea waters that have a very large potential that has been expressed, then to be able to proxies the richness of the sea waters, the fishermen use motorboats in addition to traditional fishing boats to conduct fishing. Fishing vessels with catch volume below 5 GT (Gross Ton) get a subsidy of Diesel Fuel [5]. The total cost incurred by fishermen for sea activities is $70 \%$ for the cost of diesel [6], wherewith the stability of prices will greatly help fishermen in increasing income, this can be seen from the research conducted by Subhechanis Saptanto, Achmad Zamroni, Andrian Ramadhan and Rizky Aprilian Wijaya on Policy Analysis of the Impact of Subsidized Fuel Price Adjustment for Fishermen[7]. Looking at the size of the cost component that must be provided by the fishermen for seafaring purposes of that size, it is appropriate if the government subsidizes diesel to the needs of the fishermen so that the profit margin obtained by the fishermen can be increased which ultimately impacts the fishermen in Indonesia with increasing living standards, this is revealed from the research conducted by Ade Novalina and Wahyu Indah sari who conducted an Analysis of the Impact of Rising Fuel Prices on the Resilience of Disposable Income of Village Fishermen Bagan Kecamatan Percut Sei Tuan which shows a significant relationship between rising diesel fuel prices affects the living standards of fishermen[8]. Besides the government protects the fishermen to get diesel at an affordable price and the certainty of the existence of diesel available on the one hand and the other hand can be ensured the distribution of diesel to fishermen motor users up to 30 GT [9] is not misused by irresponsible users can be done, so that the provision of diesel fuel subsidies on target, this is in line with research conducted by Siti Hajar Suryawati and Tenny Apriliani who researched the Subsidized Fuel Distribution Mechanism In Small Scale Fishing Business [10].

In this study, researchers made a breakthrough by making a breakthrough from the Governance of The Provision of diesel fuel Fishermen through Mapping on Fishermen Activities, so that recorded the number of fishermen who will go to sea every time accurately, the certainty of data of traditional fishermen and fishermen using motor, can be known of the overall needs of diesel, so that monitoring and planning the provision of diesel within a certain period of time can be predicted accurately, the availability of data on the distribution of diesel to fishermen transparently, where fishermen in the category of obtaining diesel fuel subsidies and non-subsidized diesel can be done, the fishermen who receive diesel fuel subsidies can be guaranteed for availability and the use of subsidized diesel can be avoided and reduced.

\section{RESEARCH METHOD}

In this research, the theoretical framework used is to apply the Agile Development Methods model, because this methodology relies on software engineering to build a quality software based on the completeness of the requirements and orientate objects that focus on model development by using Unified Modeling Language (UML) [11], has the following stages: 


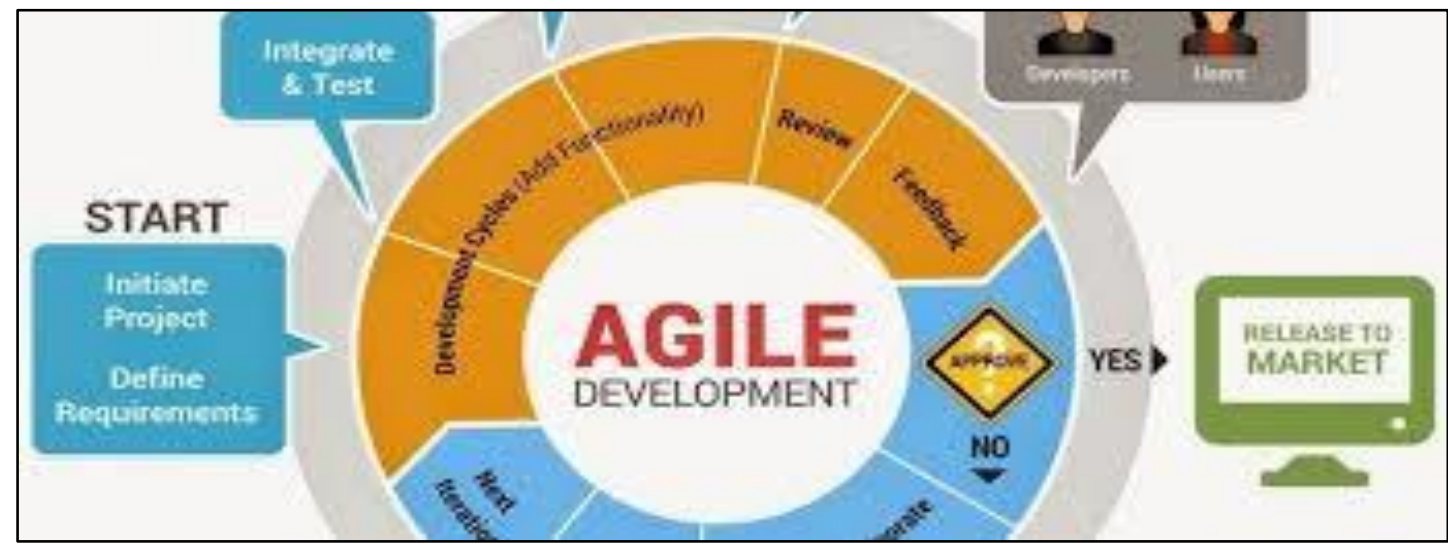

Figure 1. Agile Development Methods

1) Planning, in this step the developer and client make a plan about the needs of the software to be created.

2) Implementation, part of the process by which the programmer encodes the software.

3) Software test, here the software that has been made in the test by the quality control section so that the bugs found can be repaired immediately and the quality of the software is maintained.

4) Documentation, after the software test the next step is the software documentation process to facilitate the maintenance process in the future.

5) Deployment, which is a process carried out by the quality guarantor to test the quality of the system. Once the system is qualified then the software is ready to be deployed.

6) Maintenance, the last step is maintenance. No software is $100 \%$ bug-free, therefore it is very important that the software is maintained periodically.

\subsection{Conceptual Framework of Research}

Research scheme to build an integrated system with a business model approach, to produce accurate information on the needs of fishermen as a whole in terms of meeting the needs of diesel where there will be classification on the use of diesel in the group of fishermen receiving diesel fuel subsidies and non-subsidized fishing groups.

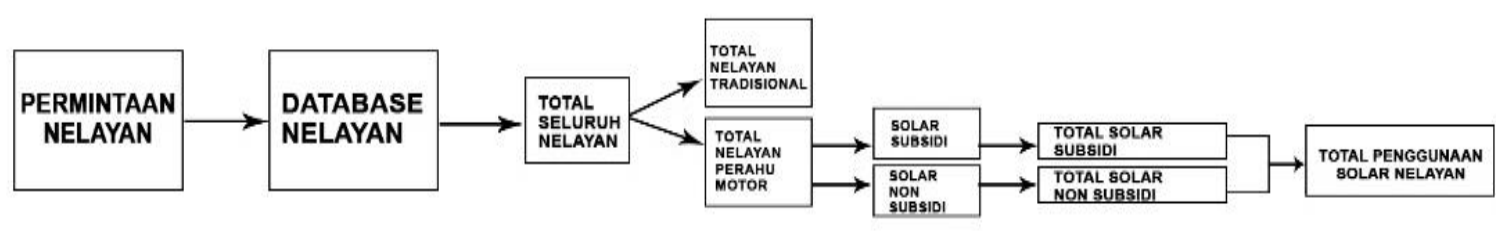

Figure 2. Business process of Fisherman Diesel Fuel Supply System

1) In the fishermen's diesel fuel supply system, data is obtained from all fishermen, both traditional fishermen and motor fishermen.

2) From the data will be managed by a database system to find out how many traditional fishermen and how many motorboat fishermen. 
3) The motor fishermen data shows how many fishermen will be given subsidized diesel fuel and how many fishermen are non subsidized.

4) From the data collection of fishermen receiving diesel and non-subsidized subsidies, it can be seen with certainty how much diesel motorboat fishermen use.

\subsection{Integrated Systems Conceptual Framework}

The conceptual framework of the fishermen's diesel fuel supply system built using Agile development is implemented in a conceptual form whose description will be built as follows:

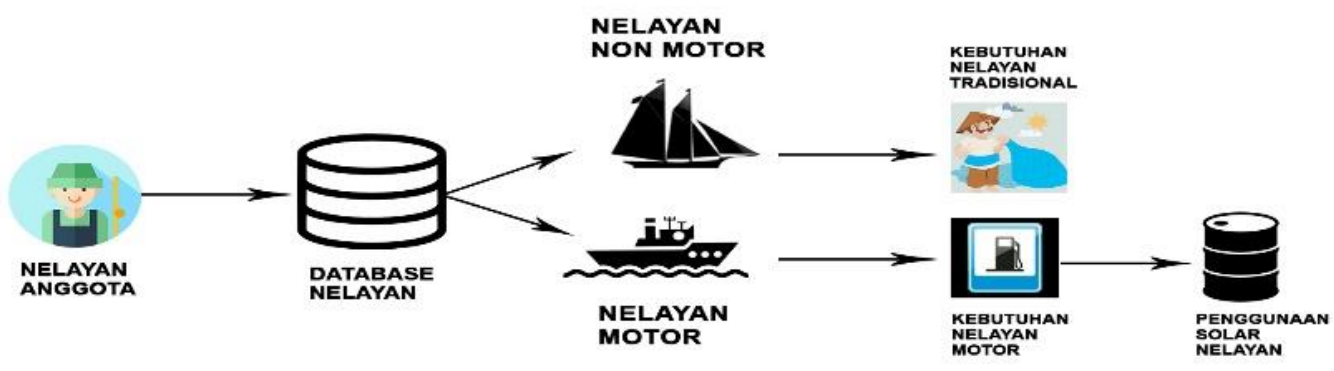

Figure 3. Conceptual Framework of Research Systems

Figure 3 is a research workflow implemented in an integrated system of supplying diesel fuel for fishermen which is built as follows:

1) Every fisherman who will go to sea, will be recorded in the fishermen database system.

2) From the data collected by the database system, it can be seen whether the fishermen are traditional fishermen or motorboat fishermen.

3) For each motorboat fisherman, it can be seen whether the motorboat used is the type of motorboat that receives diesel subsidies or not.

4) Meanwhile, for traditional fishermen, the database system will provide for other needs while fishing other than diesel.

5) The database system provides information on the number of all fishermen who are at sea.

6) The database system produces how many traditional fishermen go to sea and how many motorboat fishermen go to sea each day.

7) The database system provides information about subsidized diesel and non-subsidized diesel fuel every day.

8) The database system provides information on how much diesel is the requirement of all motorboat fishermen.

9) The database system can provide detailed information in the form of reports on the number of fishing vessels classified as traditional fishermen, vessel volume so that it can be predicted what is the minimum number of catches of all traditional fishermen every day.

10) The database system can provide detailed information in the form of reports on the number of motor fishing boats, the volume of the vessels, so that it can be predicted what is the minimum amount of catch of all fishermen on fishing boats each day. 


\section{RESEARCH RESULTS AND DISCUSSION}

In a system that is built by looking at all the needs that will be carried out by the system so that all the interests of fishermen, both for traditional fishermen and for fishermen who use motor.

\subsection{Use Case}

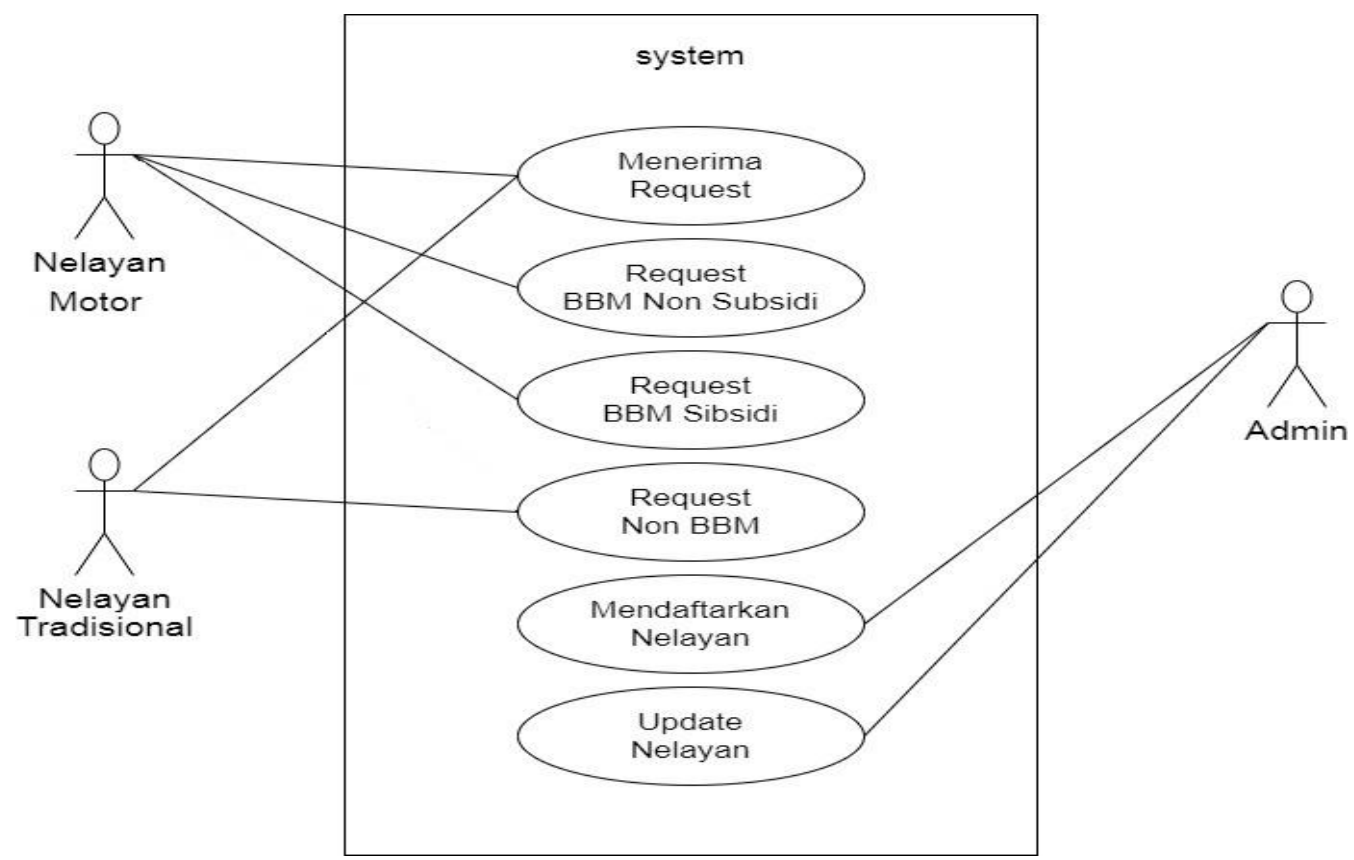

Figure 4. Use Case Diesel Fuel Supply System

Figure 4 shows the interaction of all users who use the system where:

1) Admin user, registers all fishermen who will go to sea and update fisherman data to meet fishermen's needs.

2) Motor fisherman users ask the system to provide all the necessities for fishing as well as diesel needs for either subsidized diesel or non-subsidized diesel.

3) Traditional users ask the system to provide the need for fishing.

\subsection{Class Diagram}

In the data architecture system that is built on the diesel fuel supply system, it can be seen in Figure 5 which can be explained as follows: 


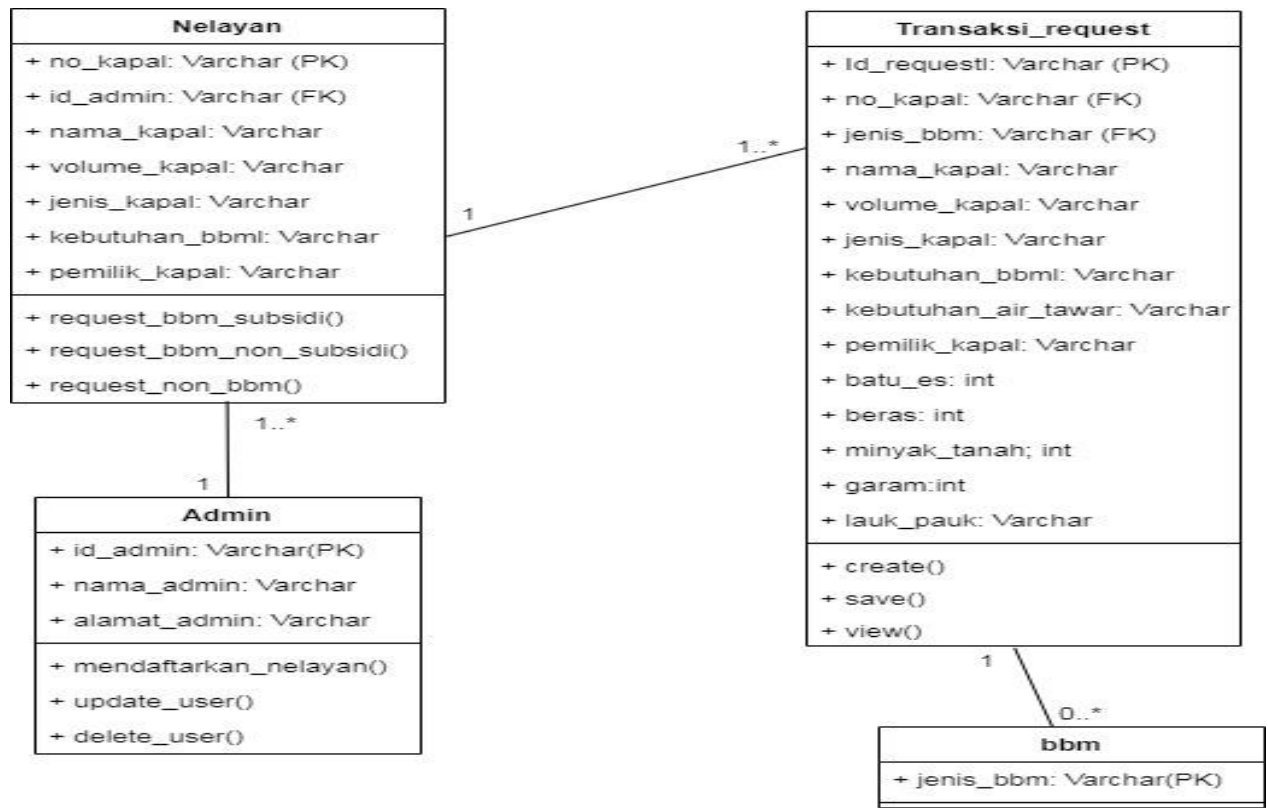

Figure 5. Class Diagram Diesel Fuel Supply System

1) All the needs of each fisherman will be related to the transaction_request class.

2) All fishermen who will use the system and the necessary needs to sea from each ship used both traditional and motor recorded in the database system managed by admin.

3) The demand for diesel fuel whether subsidized or non-subsidized occurs when all the needs requested in the system, then the system will provide the needs of the dieselbased on the data in the database system.

\subsection{Implementation on Application System}

As the design of the diesel fuel supply system, the resulting application system is as follows:

\subsubsection{System Shows First Display}

In this section the system is ready to interact with the user, as seen in Figure 6 where the system is used based on the following user levels: 


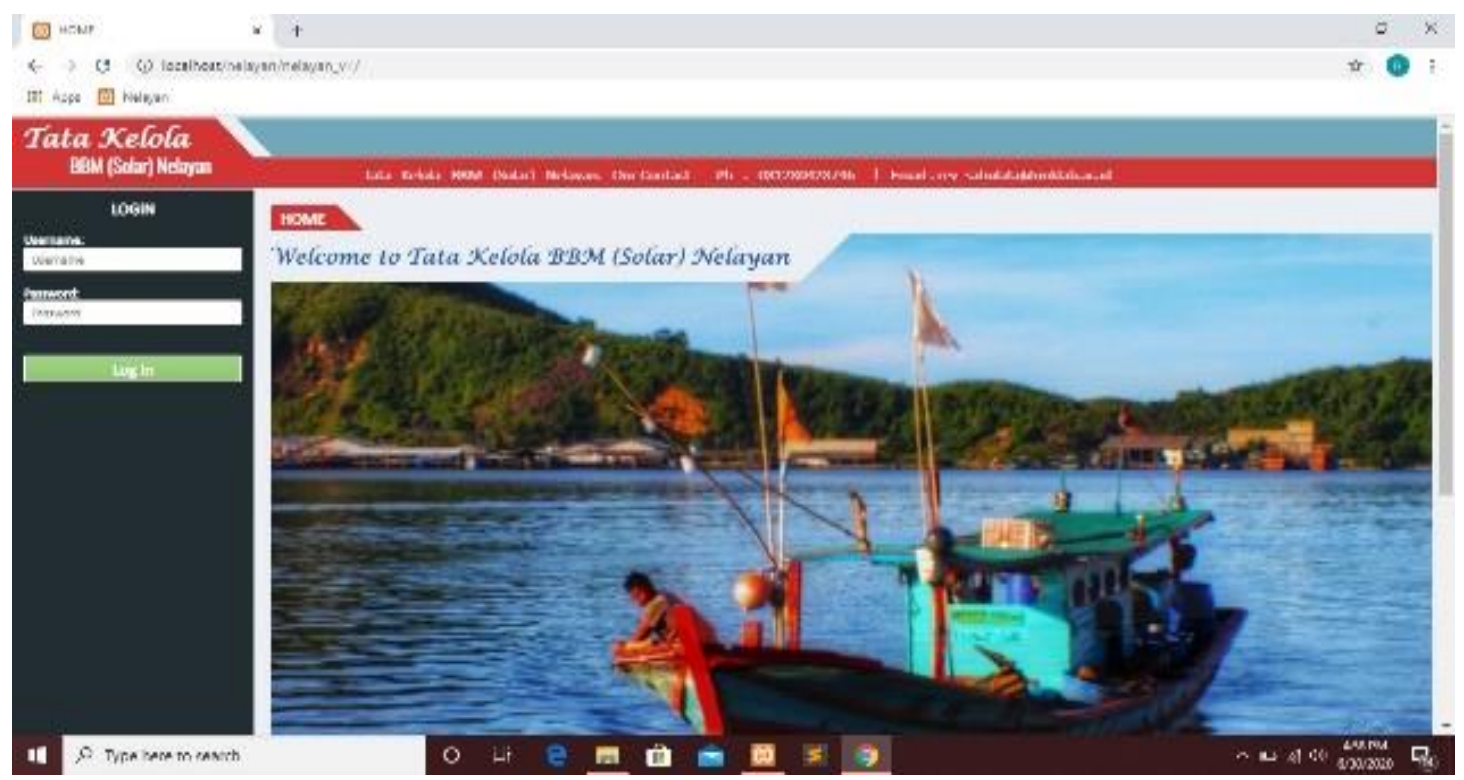

Figure 6. The First Menu for Providing Diesel Fuel

\subsubsection{User Table}

The admin user input/registers all fishermen who use the diesel fuel supply system, as seen in Figure 7 below, which displays the user name along with the username, user level, and user active status:

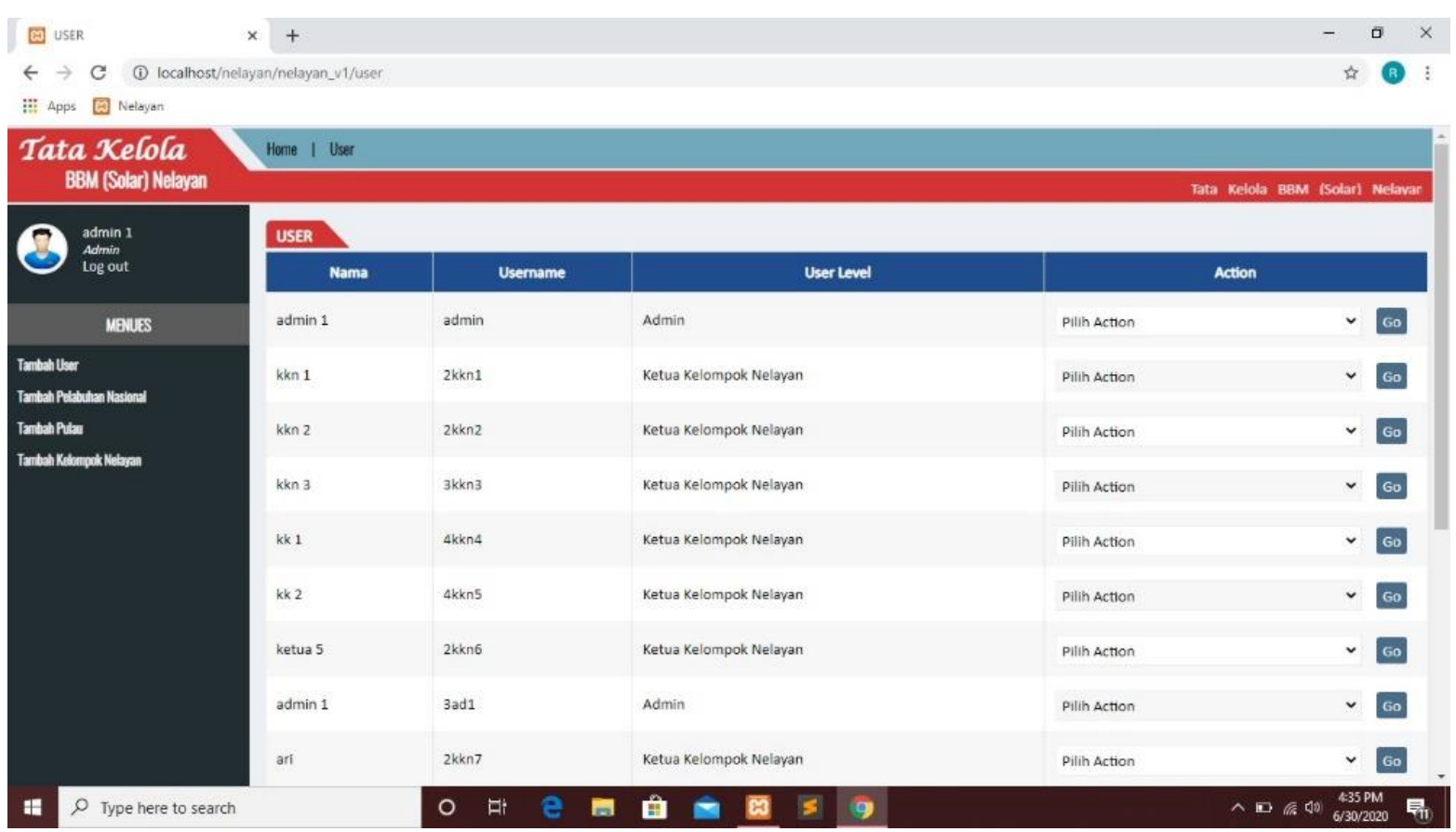

Figure 7. Register User 


\subsubsection{Input Ship Data}

As with the design of the diesel fuel supply system, so that all fishermen's needs can be met, data collection on the vessels used is a requirement where it will be known whether the motorized boat used to go to sea is getting subsidized or non-subsidized diesel by input data on ship name, ship number, name Fishermen Group and Ship Volume Size (Gross Ton). For this purpose, the system performs data retrieval as shown in Figure 8.

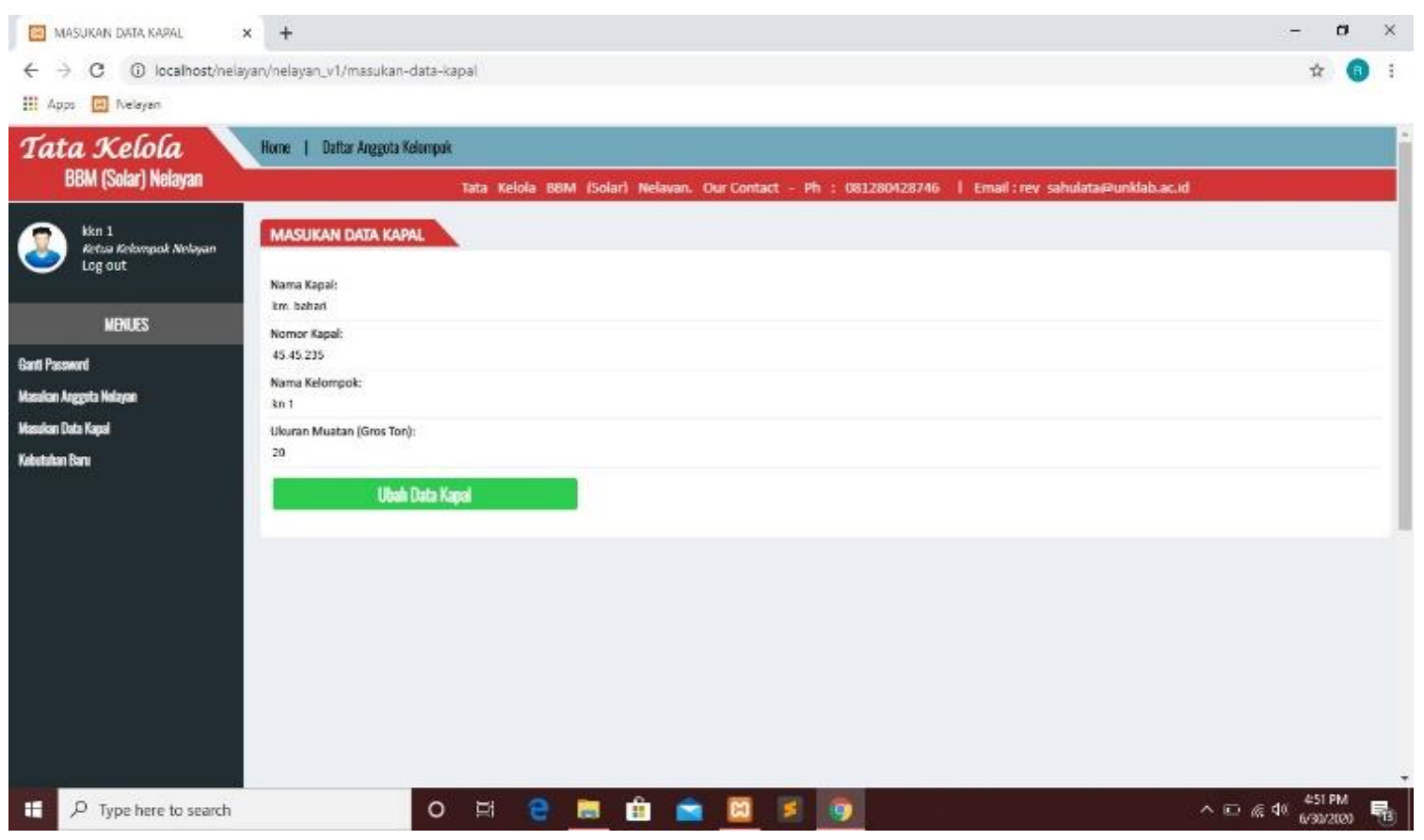

Figure 8. Input ship data

\subsubsection{Fishermen's Needs}

After the system knows about the volume of ships that will go to sea, then the system can determine whether the ship in question is the type of ship that is entitled to get subsidized diesel or use non-subsidized diesel or just traditional fishing boats. At this stage, the system has been able to calculate how much diesel is needed both for diesel subsidies and nonsubsidies. As seen in figure 9, where the amount of diesel used, the price/liter before the subsidy is summarized and other needs are blocks of ice, salt, rice, side dishes, freshwater, and kerosene or gas to cook at sea. 


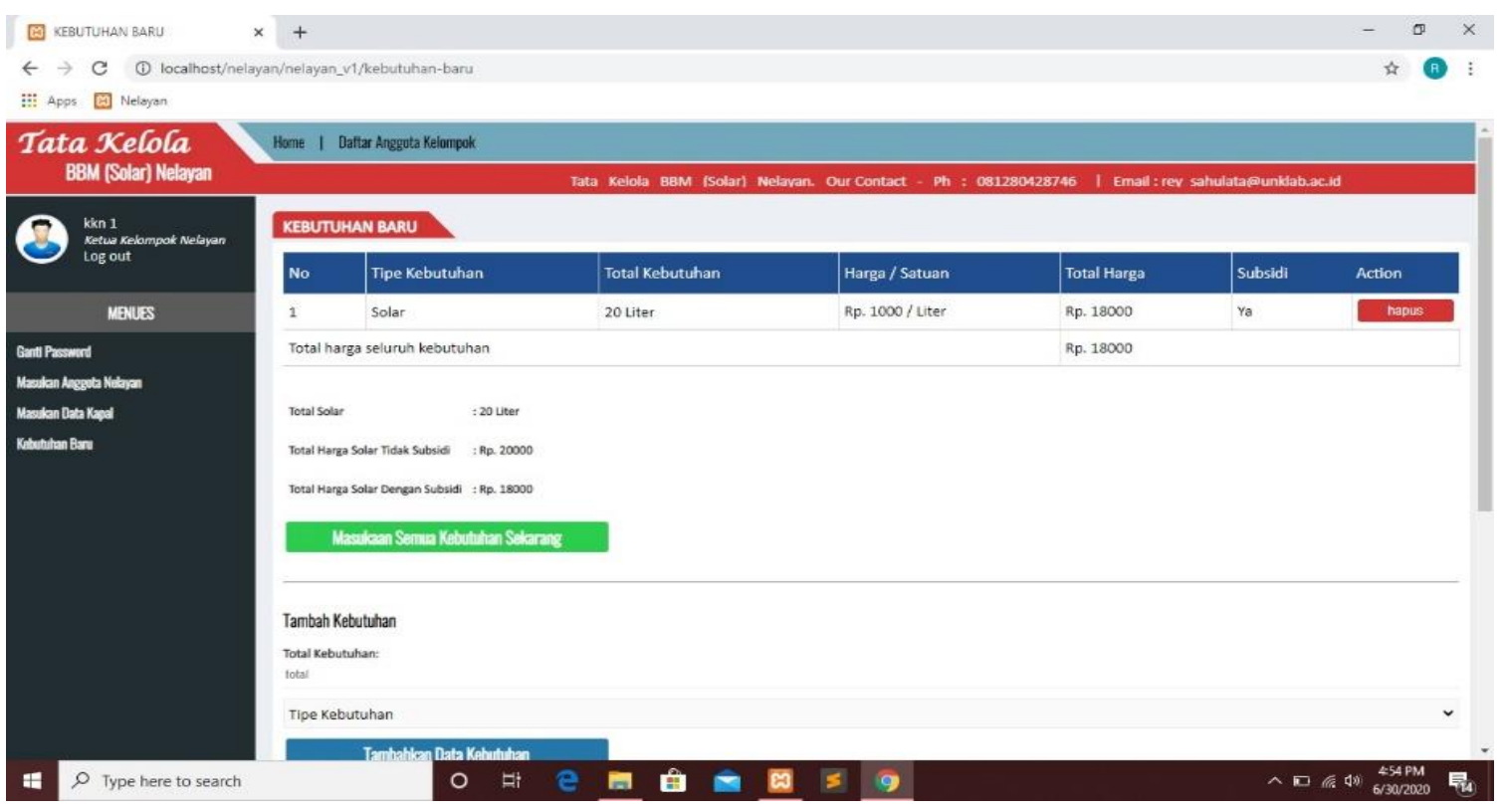

Figure 9. Fishermen's Needs

From this menu can be known the amount of diesel needed both subsidies and nonsubsidized diesel, as well as the total diesel fuel needed by all fishermen. Similarly, it can be known how much the need to go to another sea can be known for sure.

\section{CONCLUSION}

From the results of this research can be concluded:

1) All fishermen can be known ship data and can be known all the necessary needs both for diesel fuel and non-fuel needs.

2) It can be known the total use of diesel from all fishermen, as well as how much subsidized and non-subsidized diesel fuel used.

3) Each ship gets diesel fuel in accordance with the condition of the ship, which is subsidized or non-subsidized fuel.

4) The amount of diesel available in the right amount of suit.

\section{SUGGESTED}

1) There are visualizations of fishermen in the form of diagrams both overall, as well as the division of fishermen based on the vessels used.

2) 2. There is a visualization of the use of diesel fuel, in the form of diagrams divided into subsidized and non-subsidized diesel fuel.

3) 3. Estimated use of diesel fuel based on use per period 


\section{REFERENCES}

[1] Bourguignon, F. dan Pleskovic, B., 2006, Annual World Bank Conference on Development Economics Global : Rethinking Infrastructure for Development, Washington DC 20433.

[2] Kementrian Komunikasi dan Informasi Republik Indonesia, 2019, Ekspor Naik, Ikan dari Indonesia Diterima di 147 Negara, https://www.kominfo.go.id/content/detail/16072/ekspor-naik-ikan-dari-indonesiaditerima-di-147-negara/O/berita, diakses tgl 05 April 2020.

[3] Pusat Penelitian Oseanografi Lembaga Ilmu Pengetahuan Indonesia (P2O LIPI), 2019, Potensi Kekayaan Laut Indonesia Ternyata Capai $\mathrm{Rp} 1.772$ Triliun, https://kumparan.com/@kumparansains/potensi-kekayaan-laut-indonesia-ternyatacapai-rp-1-772-triliun-1qwD2eNqulO, diakses tgl 08 April 2020.

[4] Mongabay situs berita lingkungan, 2019, Kala Nelayan Tradisional Masih Hadapi Beragam Kendala, https://www.mongabay.co.id/2019/06/21/kala-nelayan-tradisionalmasih-hadapi-beragam-kendala/, diakses tgl 10 April 2020.

[5] Badan Pengatur Hilir Minyak dan Gas Bumi, 2014, BPH Migas Terima Kunjungan Kerja DPRD Kota Tegal, https://www.bphmigas.go.id/page/91/?lang=in_ID.utf8\%2C\%20in_ID.UTF$8 \% 2 C \% 20 i n \_I D \% 2 C \% 20 i n a \_I D \% 2 C \% 20 i d \% 2 C \% 20 b a h a s a-$ indonesia\%2C\%20bahasa.indonesia\%2C\%20indonesia\%2C\%20indonesian\%2C\%20su matra\%2C\%20jawa\%2C\%20kalimantan\%2C\%20sulawesi\%2C\%20papua\%2C\%20rep ublik-indonesia\&start=76, diakses tgl 10 April 2020.

[6] Republika.co.id, 2014, Nelayan Indramayu Terkena Dampak Pengurangan Solar Bersubsidi, https://nasional.republika.co.id/berita/n9s3n6/nelayan-indramayu-terkenadampak-pengurangan-solar-bersubsidi, diakses tgl 10 April 2020.

[7] Novalina, A., Sari, W.I.,2017, Analisis dampak kenaikan harga BBM terhadap ketahanan disposable income nelayan desa Bagan Kecamatan Percut Sei Tuan, Jurnal Kajian Ekonomi dan Kajian Publik, Vol. 2 No.1, hal 1-12.

[8] Jaringan dokumentasi dan informasi hukum kementrian kelautan dan perikanan republik indonesia, 2015, Permen PKP No 13/permen-KP/2015, http://jdih.kkp.go.id/peraturan/13-permen-kp-2015.pdf, diakses tgl 20 Juni 2020.

[9] Suryawati, S. H., Apriliani, T., 2015, Mekanisme penyaluran bahan bakar minyak bersubsidi pada usaha perikanan tangkap skala kecil, Jurnal Kebijakan Sosial Ekonomi Kelautan dan Perikanan, Vol. 5 No.1, hal 37-46.

[10] Kendall, K. E., dan Kendall, J. E., 2011 System Analysis and Design, Prentice Hall, New Jersey. 